\title{
Honor as a Barrier in Adapting Technology in Language Learning Context in Oman
}

\author{
Lucas Kohnke \\ American University of Afghanistan, Kabul, Afghanistan \\ Email: lucaskohnke@gmail.com
}

\begin{abstract}
This study investigated a barrier to adopting technology in a language learning context among Omani College students. The barrier examined was honor - to see if it affected female usage of the internet. The study used a questionnaire, complemented by semi-structured interviews with teachers and students at Nizwa College of Technology, Sultanate of Oman who volunteered to participate in the study. The results of the questionnaire were quantified, while the interviews augmented the results and provided relevant insights. The study found a gender divide regarding computer usage: parents consider the computer and the Internet suitable for the male members of the family but not for the female members; female students are discouraged from using the Internet, particularly instant messaging and social network sites such as Facebook due to fear of gossip and potential harm to the family honor.
\end{abstract}

Index Terms — barrier, honor, Oman, internet, technology

\section{INTRODUCTION}

The introduction of computer technology and the Internet has had significant effects on second language teaching and learning in the Gulf States. In today's dynamic and fast moving world computer literacy has become an essential necessity for good job prospects in the region.

Little research has been done in reference to Arab learners and Oman who are living in a society, where traditions and cultural values centers on family ties, and where a new educational technology, such as the Internet, might be seen as a threat to the values that are core to the culture, therefore, leading to rejection or a strong resistance of non-standard classroom instruction such as the usage of the educational technology.

This paper explore if there is an interlinking effect between honor and female usage of the Internet, as well as their relation to the educational environment.

\section{A. Arab Culture}

Family is the center of Arabic life. From early childhood and continuing through adulthood, Arabs are taught to always honor and respect their family. Because the Arab family's favorable reputation is considered paramount, honor is protected and defended at all costs. Shame, especially against family, is avoided and criticism is taken very seriously because bad actions not only dishonor an individual but also an entire family unit. These elements or Arab culture are reflected in the behavior of its members ("Bedouin-Arab Families - Family Dynamics in Bedouin-Arab Society," 2000). Family authority is related to age and gender, which adheres to the typical patriarchal model ("Arab Cultural Awareness," 2006), and "the Arab family is the center of all loyalty, obligation and status of its members" (Guide to Arab Culture, 1999, pg. 17).

Whereas in Western society, the family is important, but not considered to be central to Western life. Honor and shame, although significant, are usually not viewed as key elements to the Western Family dynamic.

\section{B. Cultural Impediments}

In Arabic societies, customs and values center on family ties. More emphasis is placed on connections with people in the community than isolation and self-autonomy. As such, the "concept of privacy and trust are embedded in cultural practices" (Al-Ani \& Redmiles, 2004, pg. 1.). Traditions and culture continues to be a strong influence on their daily practices. The older generation holds the greater power and the "younger generation typically defers to their wisdom" (Smith \& Dunckley, 1998, pg. 1) and the younger generation has been molded into submissive members of the family group. In the case of Oman and the Nizwa College of Technology, the students are from rural and traditional areas of the Sultanate. Many are the first generation in their families to receive a higher education, and the first generation to have access to the Internet.

Since Arabic cultural values revolve around family ties, a new technology like the Internet has to overcome the "strangers in our midst" factor (Al-Ani \& Redmiles, 2004, pg 1.). Otherwise, it might be perceived as a threat to the values that are core to the culture in which they exist and lead to rejection of the new technology as a result. According to Gunn (2003), interactions that take place through electronic channels lose none of the socio-cultural complexity and gender imbalance that exist within a society. 


\section{Internet Usage}

In 2008, 465,000 people (total population 2,957,717) accessed the Internet in Oman, which ranked the country 110th in the world ("CIA World Fact Book," 2010). There are gender differences between female and male usage of the Internet in the Arab world. Because the Arab world follows a patriarchal model, "Arabic women in the Arab world need to cross bigger social and cultural hurdles in using the Internet" (Ning Shen \& Shakir, 2009, pg. 4). Cultural traditions limit their communication with people outside their close family network. In fact, "children are taught and molded to be able to integrate into their immediate social environment "(Guide to Arab Culture, 1999, pg. 17). Using the Internet, email, chat room, online discussions, and online games, may all represent a strong conflict with traditional cultural and social gender from Arabic women. The Arab culture definitely "frowns at and does not condone some of the things people do on the web" (AKinyemi, 2003, pg. 3). Since the Arab society believes it is necessary for the women to "live up to these expectations" (Al-Khayyat, 1990, pg. 23), the women are closely supervised in an effort to preserve the family's honor.

According to Ayed (2005), the Internet plays an important role in shaping the political attitudes and culture among youth. The young generation in the Arab world are influenced by both Islamic and modern cultures (Solberg, 2002), which often do not stay in harmony. Even though the Arab youth are faced with these frequently-conflicting ideologies, "research about Internet usage in the United Arab Emirates has proven that they have kept firm ties to their cultural tradition "(Ning Shen \& Shakir, 2009, pg. 5).

\section{Parental Control}

As mentioned earlier authority in Arab society is generally related to age and gender ("Arab Cultural Awareness," 2006). Male family members believe that any shame from which the Arabic family might suffer will most likely be caused by their female relates. As such, the males feel responsible for the females, and control them through their lives. Hence, parents and brothers might be afraid that the women of the family gossip. Since gossip mainly involves "shame and shameful behavior, fear of gossip may make parents spy on their children" (Al-Khayyat, 1990, p. 23). Since honor is the most important thing to Arab families, Arab's try to limit that their daughters are being talked about. As gossip operates as one of the "strongest forms of social control" (Al-Khayyat, 1990, p. 23) Gossip could occur using the Internet through instant messaging or email because interaction online is faceless and there are no restrictions of race, color, sex and religion. The interaction patterns cannot be easily controlled between the male and female students. Hence, the religious barriers collapse online!

Parents play an important role in their children's ICT adoption behavior because they will pay for the computers and connections. Thrane (2003) listed two main factors influencing the ICT adoption in teenagers' homes: economic affordability (whether the parents are able to afford the ICT) and utilities (whether the ICT can meet their needs or desires and offer children opportunities to learn at the same time). When the financial situation allows, parents are usually active in buying their children new ICTs if needed. In the case of the students at NCT, the majority is from rural and economically underdeveloped areas of Oman, and consequently has limited access to the Internet at home.

However, parental control in teenagers' ICT adoption and use is always complex and contradictory. New ICTs cause apprehension amongst parents for two main reasons: first for fear that their children will be spending too much time on these devices and less time with the family (Thrane, 2003), and second, for fear that their children will be exposed to all types of negative information and in appropriate (Tiemann, 2007; Ferran, 2008). These worries, in turn, may impel parents to rethink the adoption of ICTs (Ling \& Yttri, 2002), or monitor and set rules on the use of these devices (Campbell, 2005).

\section{RESEARCH METHODS}

The purpose of this study was to find out why certain teachers, relatives and male student discourage female students from using the Internet. Methods of data collection included both quantitative and qualitative research methods such as questionnaires and interviews.

To compensate for the limitations of the survey method, semi-structured interviews were used to gather data. Interviewing is one of the most powerful tools used to understand people's points of view, beliefs and attitudes. This is because of its interactive nature, interviewing has many advantages over other types of data collection strategies (Best \& Kahn, 1998). The interviews compliment the survey instrument by providing better understanding of contexts, as if offers solid descriptions and explanations for the quantitative data in the study (Lincoln \& Guba, 1985).

The questionnaire asked how their parents view the Internet, whether anyone such as their brothers, sisters or friends monitor their Internet usage and if anything negative has been said regarding the Internet in relation to their usage. Any kind of control of the usage of the Internet is an important factor that affects the adoption and usage of the Internet. For example, they were asked: "How do your parents view the Internet?"; "Do your parents/brothers/sisters check your emails and/or whom you are chatting with?"; "Has a teacher ever told you that the Internet can be harmful?" etc.

There were also open-ended questions in this part to help with further analysis, they are also asked to explain in their own worlds why they make those choices.

\section{A. Questionnaire}


The questionnaire asked how their parents view the Internet, whether anyone such as their brothers, sisters or friends monitor their Internet usage, and if anything negative has been said regarding the Internet in relation to their usage. Any kind of control of the usage of the Internet is an important factor that affects the adoption and usage of the Internet. For example, they were asked: "How do your parents view the Internet?"; "Do your parents/brothers/sisters check your emails and/or whom you are chatting with?"; "Has a teacher ever told you that the Internet can be harmful?" etc.

There are also open-ended questions in this part to help with further analysis, they are also asked to explain in their own worlds why they make those choices.

\section{B. Interview}

The purpose of the semi-structured, one-to-one interviews was to explore further, provide depth, or clarify points raised by the responses to the questionnaire. The interviews lasted approximately 10-15 minutes per subject and subjects were asked about item responses on the questionnaire which turned out to be crucial to the study.

\section{Subjects}

The student participants of the study are second and third semester students attending a two to four semester intensive foundation studies program in English.

The student participants in the present study are 20 students. The mean age of them is 18.7 . The first language of all the student participants is Arabic. 12 of the student participants are boys and 8 are girls. All of the participants graduated from High School in one of the Omani governmental schools. The student participants are placed in one of 4 levels (pre-elementary, elementary, intermediate, and advanced) according to their placement scores. They are exposed to English 20 hours a week.

\section{RESULTS}

Question 1 received mixed responses from students on how their parents view the computer and how they view the Internet (Question 2). 65\% of the female students said their parents don't want them to use a computer or the Internet and commented that "our parents don't really know what a computer is or what it can do, so they don't trust us to use one." Whereas, $25 \%$ of the female students said that their parents thought it was a great intervention and useful for their studies. All the male students answered that their parents think it is useful for their studies, even though the parents might not know what a computer is.

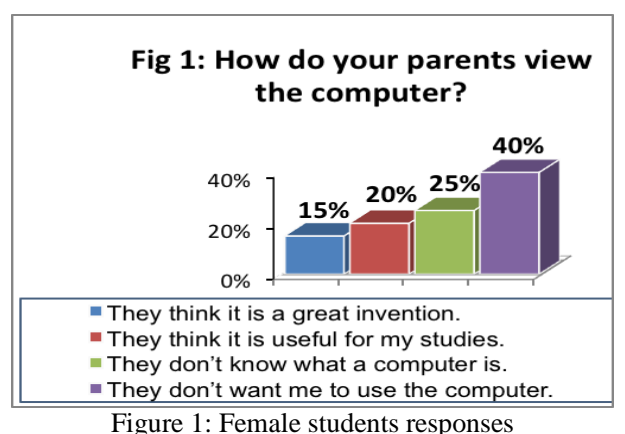

None of the male students said their parents/brother/sisters check on the students' emails and/or whom they are chatting with (Question 4). Whereas, 30\% of the girls answered they do not really know if it happens, and $25 \%$ said it happens sometimes.

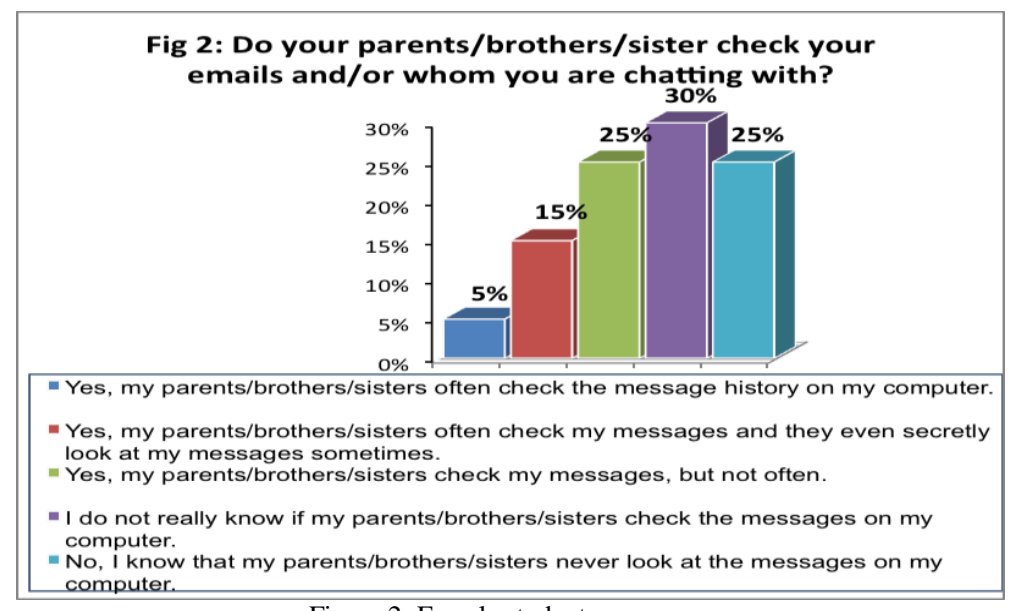

Figure 2: Female students responses 
All of the students have at one time or another been told that the Internet can be harmful (Question 5) by a member of their family. Only $10 \%$ of the male students have been told that the Internet can be harmful by a friend (Question 6), whereas all the girls had one time or another been told that it can be harmful. However, what is striking is that $70 \%$ of the female students said Muslim teachers had told them that the Internet can be harmful (Question 7) and that they should not chat or interact online with male counterparts.

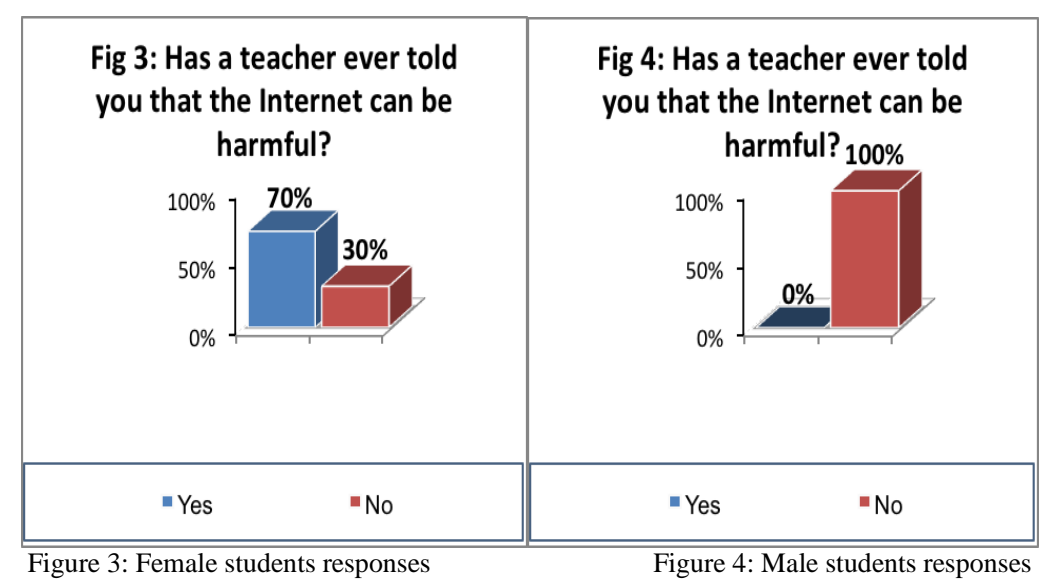

\section{DISCUSSION}

The paper sets out to answer why certain teachers, relatives and male students discourage female students from using the Internet. This is imperative in understanding the underlying reasons why female students decide to adopt, or not, technology in a language learning context in Oman. This section will outline the 3 main reasons for the above.

In Oman, as in many countries in the Gulf region, cultural traditions limit female communication with people outside their own immediate family and the opposite gender. By and large it is "not suitable for non-family members of the opposite sex to approach for conversation or other casual encounters" (Guide to Arab Culture, 1999, p.22).

Hence, using the Internet represents a strong conflict, being seen as a threat to the core values that center around Arab families. Furthermore, religion is an important aspect of students perception of "self" (Canning \& Bornstein, 2001) and they are expected to live up to certain expectations. The Arab teachers felt the need to protect the female students' students honor and from the shame that they think could occur if they interacted with the opposite gender online. In other words protecting and preserving Arab socio-cultural values (Akinyemi A, 2003).

The older generation holds a greater power, "they are considered a blessing in the family and their opinion is respected and valued" (Arabic Cultural Profile, 2008, pg.4). The younger generation typically "defers to their wisdom" (Smith \& Dunckley, 1998, pg. 1) and as such many students listen to their teachers as "authority figures and trust their judgment" (Arab Cultural Awareness, 2006, pg 57). Furthermore, this was not only limited to the college, female students are also being discouraged by family members such as their older brothers, parents and figure heads in their neighborhood. The male members of the family in Oman feel responsible for the female members and want to protect and keep them innocent. Several female students pointed out that they are afraid of gossip; gossip could bring shame on themselves and their family, which has been documented in previous studies by Al-Ani \& Redmiles (2004). This was also indicated in the present study in the interviews as a strong deterrent from using the Internet. Especially, since honor is the most important aspect in the Omani society and given that women in Arabic/Islamic cultures are expected to adhere to certain ways and be "supervised," these findings confirm to Al-Khayyat (1990) previous writings.

Even though, the Internet is accessible to most on their cell-phones, the female Omani youth has kept firm ties to their cultural traditions as Ning Shen and Shakir (2009) found of their counterparts in United Arab Emirates.

As the account presented above indicates, female students are facing many hurdles in utilizing the full benefits of ICT in an educational aspect: (i) cultural traditions still dictate dictates who female students should interact with in a traditional city such as Nizwa2; (ii) the Arab teachers feel a strong sense of protection of the female students; (iii) gossip is a huge discourager as it might bring shame on them and their family.

It should therefore be clear from the above discussion that traditional values are one of the main barriers in allowing female students the freedom to use the Internet.

\section{CONCLUSION}

This paper investigated the barrier of honor and female usage of the Internet. It showed that honor is a major barrier in adopting technology in a language learning setting among Omani College students, inside and outside the classroom.

Honor plays a major part in the female students' usage of the Internet. They are afraid that "people" might start to gossip if they are seen interacting with the opposite gender online. Several of the female students had been warned that the Internet will be harmful for them and their brothers, older sisters, and/or parents might check whom they are 
communicating with online. Hence, many of the female students are discouraged from using the Internet and only use it sparingly or not at all.

The introduction of computer technology and specifically the Internet has had significant effects on communicating, teaching and learning in Middle East, but still faces many challenges. It provides an important medium for second language learners to communicate with native speakers in real situations, which is not always easily accessible in Oman, as well as improving their overall skills and learning more specifically about the target culture.

\section{APPENDIX A STUDENT QUESTIONNAIRE}

\section{How do your parents view the computer? (Multiple Choice)}

$\square$ They think it is a great invention.

$\square$ They think it is useful for my studies.

$\square$ They don't know what a computer is.

$\square$ They don't want me to use the computer. Why:

$\square$ I don't know

2. How do your parents view the Internet? (Multiple Choice)

$\square$ They think it is a great invention.

$\square$ They think it is useful for my studies.

$\square$ They think the Internet is a good way to connect with friends.

$\square$ They think the Internet is a good way to get to know new people.

$\square$ They don't know what the Internet is.

$\square$ They don't want me to use the Internet. Why:

$\square$ I don't know

3. Do your parents/brothers/sisters restrict or control your usage of the Internet? (Multiple choices)

$\square$ Yes, my parents have control over the monthly cost of my Internet access.

$\square$ Yes, my family members control whom I contact on the Internet in order that I avoid bad influences.

$\square$ Yes, my parents control how long I can use the Internet to ensure that I spend enough time on my studies.

$\square$ No, they don't control my use of the Internet at all.

$\square$ List any other reason(s) why your parents control your use of the Internet.

\section{Do your parents/brothers/sister check your emails and/or whom you are chatting with?}

$\square$ Yes, my parents/brothers/sister often check the message history on my computer.

$\square$ Yes, my parents/brothers/sisters often check my messages and they even secretly look at my messages sometimes.

$\square$ Yes, my parents/brothers/sisters check my messages, but not often.

$\square$ I do not really know if my parents/brothers/sisters check the messages on my computer.

$\square$ No, I know that my parents/brothers/sisters never look at the messages on my computer.

5. Has a family member ever told you that the Internet can be harmful?

$\square$ Yes

$\square$ No

$\square$ If yes, what was the reason:

6. Has a friend ever told you that the Internet can be harmful?

$\square$ Yes

$\square$ No

$\square$ If yes, what was the reason:

7. Has a teacher ever told you that the Internet can be harmful?

$\square$ Yes

$\square$ No

$\square$ If yes, what was the reason:

\section{REFERENCES}

[1] Arab Cultural Awareness. (2006). Office of the Deputy Chief of Staff for Intelligence, US Army Training and Doctrine Command Ft. Leavenworth, Kansas. Retrieved March 30, 2010, from www.fas.org/irp/agency/army/arabculture.pdf

[2] Al-Ani, \& Redmiles, D. (2004). Forces that Influence Trust in Technology in the Middle East: Culture, Politics and History. Retrieved on March 28, 2010, from http://mikeb.inta.gatech.edu/HCI4CID/AlAni.pdf

[3] Akinyemi, A. (2003). Web-Based Learning and Cultural Interference: Perspectives of Arab Students. In A. Rossett (Ed.), Proceedings of World Conference on E-Learning in Corporate, Government, Healthcare, and Higher Education 2003 (pp. 1858-1862). Chesapeake, VA: AACE. Retrieved from http://www.editlib.org/p/12239.

[4] Arabic Cultural Profile. (2008). Retrieved July http://www.sermrc.org.au/uploads/mrc_resources/Arabic\%20community\%20profile.pdf 
[5] Al-Khayyat, S. (1990). Honour and Shame: Women in Modern Iraq. London: Saqi books. London: Rutledge.

[6] Ayed, H. A. (2005). The Influence of Internet in the Political Culture (A Field Study). Journal of Social Sciences, 1(3), 128135.

[7] Bedouin, Arab Families, Family Dynamics in Bedouin Arab Society. (2000) Retrieved on April 24, 2010 from http://family.jrank.org/pages/156/Bedouin-Arab-Families-Family-Dynamics-in-Bedouin-Arab-Society.html

[8] Best, J.W., \& Kahn, J.V. (1998). Research in education (8thed.). Boston: Allyn and Bacon.

[9] Canning, C., \& Bornstein, L. (2001). Issues in the Development of EFL Cost Recovery Courses in the Arab World. Retrieved on May 19, 2010 from http://www.eltnewsletter.com/back/November2001/art812001.htm

[10] Campbell, M. (2005). The impact of the mobile phone on young people's social life. In: Social Change in the 21st Century Conference, 28 October 2005, QUT Carseldine, Brisbane. Retrieved on April 27, 2010 from http://eprints.qut.edu.au/3492/1/3492.pdf

[11] CIA World FactBook, (2010). Retrieved on October 2, 2010 from https://www.cia.gov/library/publications/the-worldfactbook/geos/mu.html

[12] Ferran, L. (2008). Parental Controls for cell phones, GPS, phrase recognition and speed alerts let parents monitor kids' cell phones. Retrieved on April 3, 2010 from http://abcnews.go.com/GMA/Parenting/Story?id=6529871\&page=1

[13] Gunn, C. (2003). Dominant or Different? Gender Issues in Computer Supported Learning. Journal of Asynchronous Learning Networks, 7(1), 14-30.

[14] Hammad, A., Kysia, R., Rabah, R., Hassoun R., Connelly, M. (1999). Guide to Arab Culture: Health Care Delivery to the Arab American Community. Retrieved October 15, 2010 from Access Community: http://www.accesscommunity.org/site/DocServer/health_and_research_cente_21.pdf?docID=381

[15] Lincoln, Y., \& Guba, E. (1985). Naturalistic inquiry. New York: Sage Publications

[16] Ling, R. and Yttri, B. (2002). Hyper-coordination via mobile phones in Norway, in James E. Katz \& M. Aakhus (Eds.), Perpetual Contact: Mobile Communication, Private Talk, Public Performance. Cambridge University Press, Cambridge, p139 $-169$.

[17] Shen, N \& Shakir, M. (2009). Internet Usage Among Arab Adolescents: Preliminary Findings. Retrieved February 19, 2010 from http://www.iseing.org/emcis/CDROM\%20Proceedings\%20Refereed\%20Papers/Proceedings/Presenting\%20Papers/C2/C2.pdf

[18] Smith, A \& Dunckley, L. (1998). Issues for Human-Computer Interaction in Developing Countries. Retrieved on February 19, 2010 from http://mikeb.inta.gatech.edu/UCDandIDWorkshop/papers/dunckley.pdf

[19] Solberg, C. A. (2002). Culture and industrial buyer behavior: The Arab experience. Paper presented at the The 18th IMP Conference. Retrieved on September 9, 2010 from http://impgroup.org/uploads/papers/522.pdf

[20] Thrane, K. (2003). Adoption of ICT in Norwegian teenage homes. Retrieved May $1, \quad 2010$ from http://www.telenor.com/rd/pub/rep03/R_20_2003.pdf

[21] Tiemann, A. (2007). AT\&T adds parental control options to cell phones. Retrieved June 23, 2010 from http://news.cnet.com/8301-13507_3-9770506-18.html

Lucas Kohnke is currently an ESL Instructor at the American University of Afghanistan, Kabul. He has worked as an E-learning coordinator, Curriculum Developer, and Head Teacher in Asia and Middle East. He has presented at numerous national and international conferences on e-learning, social platforms, grammar and teacher training. 